\title{
Karol Kłodziński, Sekretarze ab epistulis $i$ a libellis $w$ kancelarii cesarzy od Augusta do Hadriana, Torun 2011, ss. 140
}

$\mathrm{W}$ nauce polskiej badania zarówno nad rzymskimi kancelariami cesarskimi, jak i nad rolą wielkich liberti Augusti nie zajmują należnego im miejsca. W nauce światowej zagadnienia te zostały omówione nieco szerzej, jednak nawet tutaj podstawową rolę odgrywają wiekowe już publikacje1. Wspomniane zagadnienia pojawiają się co prawda nadal w literaturze, stanowią jednak zazwyczaj jedynie tło, czy też wątek poboczny dla głównych rozważań wielu historyków. W związku z powyższym niezwykle interesująco prezentuje się wydana w tym roku praca Karola Kłodzińskiego.

Książka składa się z pięciu rozdziałów i posiada charakter chronologiczno-problemowy. W pierwszych czterech rozdziałach, opracowanych przez autora głównie metodą prozopograficzną, przedstawiono postaci sekretarzy ab epistulis i a libellis. K. Kłodziński zaprezentował kolejno sekretarzy do spraw korespondencji sprawujących swe funkcje od Augusta do Trajana (rozdział 1), ich następców za panowania Hadriana (rozdział 2) oraz sekretarzy do spraw petycji: znów od Augusta do Trajana (rozdział 3) i za Hadriana (rozdział 4). Przyjęcie takiego podziału wydaje się całkowicie słuszne, gdyż rządy trzeciego przedstawiciela dynastii Antoninów miały przełomowe znaczenie dla organizacji wielkich kancelarii. Natomiast rozdział 5 dotyczy udziału sekretarzy w procesie powstawania reskryptów cesarskich. Autor, opierając się tutaj głównie na źródłach jurydycznych, podjął udaną próbę przejrzystego omówienia mechanizmów funkcjonowania administracji centralnej. Zaprezentował także, $\mathrm{w}$ równie zadowalającym stopniu, zakres zadań powierzanych rzeczonym sekretarzom.

Omawiana praca posiada logiczną i przejrzystą strukturę. Zakres tematyczny nie może budzić zastrzeżeń, jak przypomina bowiem sam autor, to właśnie sekre-

${ }^{1}$ Por. H. Chantraine, Freigelassene und Sklaven im Dienst der romischen Kaiser, Wiesbaden 1967; P. Weaver, Familia Caesaris - a Social Study of the Emperor's Freedmen and Slaves, Cambridge 1972; G. Boulvert, Domestique et fonctionnaire sous le Haut Empire Romain, Paris 1974; F. Millar, The Emperor in the Roman World, 31 BC-AD 337, London 1977. 
tarze ab epistulis $i$ a libellis byli bardzo aktywni w kreowaniu cesarskich konstytu$\mathrm{cji}^{2}$. Także zastosowany zakres chronologiczny wydaje się całkowicie słuszny. Za panowania Hadriana doszło bowiem do przejęcia wielkich kancelarii przez ekwitów, choć nieprawdziwa jest informacja zawarta w Historia Augusta, jakoby to właśnie ten cesarz jako pierwszy powierzył funkcje sekretarzy ab epistulis i a libellis przedstawicielom ordo equester (HA, Hadrianus, 22, 8). W rzeczywistości doszło do tego już w roku 69 n.e., zwanym rokiem czterech cesarzy, który był pod wieloma względami przełomowy zarówno dla funkcjonowania kancelarii cesarskich, jak i dla pozycji liberti Augusti.

Książka K. Kłodzińskiego opiera się na niezwykle szerokiej i różnorodnej bazie źródłowej obejmującej teksty literackie, źródła jurydyczne i epigraficzne. Autor wykorzystał także wszelkie poruszające ten problem opracowania naukowe z literatury polskiej i światowej, dzięki czemu uzyskał szerokie i obiektywne spojrzenie na interesujące go zagadnienia.

Wielką zaletą omawianej pracy jest wszechstronność ujęcia tematu. Nie znajdziemy w niej co prawda informacji na temat wpływów, potęgi, bogactwa czy życia prywatnego sekretarzy, jednak prezentowanie tych kwestii nie było celem autora i w żadnym wypadku ich brak nie może być wysuwany jako zarzut. Otrzymujemy natomiast przejrzystą prezentację karier urzędniczych z jednoczesną rekonstrukcją działalności prawotwórczej dwóch wielkich kancelarii cesarskich. Poza tym podjęta próba określenia zakresu obowiązków sekretarzy ab epistulis i a libellis jest bardzo cenna nie tylko dla badaczy dziejów prawa rzymskiego, ale także dla historyków zgłębiających rolę samych wyzwoleńców cesarskich. Nie ma wątpliwości co do tego, że potęga wielu z nich bazowała głównie na osobistych relacjach z patronem. Jednak formalne określenie ich uprzywilejowanej pozycji, poprzez rozszerzenie zakresu kompetencji piastowanego urzędu, było ważnym elementem budowania własnych wpływów, tym bardziej że kompetencje te nierzadko były określane przez nich samych, na co zwrócił uwagę Stewart Irvin Oost, opisując karierę Pallasa ${ }^{3}$. Kwestia ta budziła już zresztą zaniepokojenie i oburzenie także u Tacyta (Ann., XII 60). K. Kłodziński porusza także inne ciekawe zagadnienia, jak chociażby: geneza obu kancelarii, które kontynuowały przecież pewne wypracowane już tradycje, problem wyodrębnienia sekretariatów ab epistulis Latinis i ab epistulis Graecis, czy też pochodzenie samego terminu scrinium.

${ }^{2}$ K. Kłodziński, Sekretarze ab epistulis $i$ a libellis $w$ kancelarii cesarzy od Augusta do Hadriana, Toruń 2011, s. 10.

3 S. I. Oost, The Career of M. Antonius Pallas, „The American Journal of Philology”, 1958 LXXIX, s. 124. 
Wziąwszy pod uwagę wszystkie powyższe fakty, trzeba uznać książkę K. Kłodzińskiego za pozycję niezwykle interesującą. Prezentowany przez niego warsztat historyka, bezbłędne stosowanie metod prozpograficznej i onomastycznej oraz świetna znajomość bazy źródłowej i literatury przedmiotu spotykają się z moim najwyższym uznaniem.

Artur Ryszard Jecka (Toruń)

Niewygodne dla władzy. Ograniczanie wolności stowa na ziemiach polskich $w X I X i X X$ wieku, Zbiór studiów pod redakcja Doroty Degen i Jacka Gzelli, Wydawnictwo Naukowe Uniwersytetu Mikołaja Kopernika, Toruń 2010, ss. 592

$\mathrm{K}$ westie zinstytucjonalizowanego działania cenzury, prowadzącego do ograniczania prawa do wypowiedzi i łamiącego w rezultacie wolność słowa zawielopłaszczyznowość oraz skutki, jakie wywoływała ingerencja w materiały dziennikarskie na każdym etapie przygotowywania tekstów do druku czy szerzej - następstwa oddziaływania zmanipulowanych treści na kolejne pokolenia czytelników, na kształtowanie się ich świadomości i postaw obywatelskich. Z powodu niedostępności źródeł historycznych badania różnych form działania ośrodków władzy w zakresie ograniczania wolności słowa w Polsce dziewiętnasto- i dwudziestowiecznej były utrudnione lub wręcz niemożliwe. Dopiero otwarcie zasobów archiwalnych, także tych zagranicznych (m.in. litewskich), umożliwiło studia nad zagadnieniami cenzury, a spotkania konferencyjne stały się miejscami prezentacji osiągnięć i wymiany poglądów.

Omawiany tom jest pokłosiem ogólnopolskiej konferencji naukowej „Niewygodne dla władzy. Ograniczanie wolności słowa w Polsce XIX i XX wieku”, która odbyła się w dniach 18-19 listopada 2008 r. w Instytucie Informacji Naukowej i Bibliologii Uniwersytetu Mikołaja Kopernika w Toruniu. Zamierzeniem redaktorów tomu: Doroty Degen i Jacka Gzelli było przedstawienie obrazu skali złożoności zjawiska cenzury, co w ich opinii powinno przyczynić się do szerszej refleksji na zagadnieniami, i co w rezultacie ma szansę stać się też impulsem do dalszych przedsięwzięć badawczych na tym polu. W książce zawarto 31 artykułów, każdy został opatrzony streszczeniem w języku angielskim. Zwraca uwagę staranna edycja i szata 